\title{
Ongoing global biodiversity loss and the need to move beyond protected areas: a review of the technical and practical shortcomings of protected areas on land and sea
}

\author{
Camilo Mora ${ }^{1,3, *}$, Peter F. Sale ${ }^{2}$ \\ ${ }^{1}$ Department of Biology, Dalhousie University, Halifax, Nova Scotia B3H 4J1, Canada \\ ${ }^{2}$ Institute for Water, Environment and Health, United Nations University, Port Carling, Ontario P0B 1J0, Canada \\ ${ }^{3}$ Present address: Department of Geography, University of Hawaii, Honolulu, Hawaii 96822, USA
}

\begin{abstract}
A leading strategy in international efforts to reverse ongoing losses in biodiversity is the use of protected areas. We use a broad range of data and a review of the literature to show that the effectiveness of existing, and the current pace of the establishment of new, protected areas will not be able to overcome current trends of loss of marine and terrestrial biodiversity. Despite local successes of well-designed and well-managed protected areas proving effective in stemming biodiversity loss, there are significant shortcomings in the usual process of implementation of protected areas that preclude relying on them as a global solution to this problem. The shortcomings include technical problems associated with large gaps in the coverage of critical ecological processes related to individual home ranges and propagule dispersal, and the overall failure of such areas to protect against the broad range of threats affecting ecosystems. Practical issues include budget constraints, conflicts with human development, and a growing human population that will increase not only the extent of anthropogenic stressors but the difficulty in successfully enforcing protected areas. While efforts towards improving and increasing the number and/or size of protected areas must continue, there is a clear and urgent need for the development of additional solutions for biodiversity loss, particularly ones that stabilize the size of the world's human population and our ecological demands on biodiversity.
\end{abstract}

KEY WORDS: Land protected areas - Marine protected areas - Effectiveness - Conservation · Biodiversity loss $\cdot$ Human population $\cdot$ Human consumption

\section{INTRODUCTION}

Marine and terrestrial biodiversity is decreasing due to a wide range of human effects (Baillie et al. 2004, Hails 2008, Secretariat of the Convention on Biological Diversity 2010). Approximately $40 \%$ of terrestrial net primary productivity (Vitousek et al. 1986, Rojstaczer et al. 2001) and $35 \%$ of that produced on the ocean shelf (Pauly \& Christensen 1995) are now appropriated by humans. Overall, humans have direct effects on most of the Earth's surface: globally, human activities affect $\sim 83 \%$ of the land (Sanderson et al. 2002) and $100 \%$ of the ocean, with $\sim 41 \%$ being strongly affected
(Halpern et al. 2008). As a result of our appropriation of resources and more direct impacts, an increasing number of species is threatened by extinction (Baillie et al. 2004, Hails 2008, Secretariat of the Convention on Biological Diversity 2010). This loss is occurring in spite of the goods and services that biodiversity provides to humankind, valued in the order of a few trillion dollars annually (e.g. Costanza et al. 1997; the United Nations Economics of Ecosystems and Biodiversity project [www.teebweb.org], the United Nations-backed Principles for Responsible Investment project [www.unpri. org]). In addition, several studies indicate that maintaining biodiversity is much simpler than restoring it 
and that, depending on the nature and extent of our impacts, some damaged ecosystems might never return to their original states, meaning that any imperilment or loss could be permanent (Scheffer \& Carpenter 2003). In the face of ongoing biodiversity loss, the recognized value of biodiversity and the need for steps to maintain or restore it have prompted a renewed effort to develop safeguarding strategies.

A strategy at the forefront of biodiversity conservation is the use of protected areas (PAs) (Pimm et al. 2001, Gaines et al. 2010). The rationale is that by reducing habitat loss and mortality due to harvesting, populations can grow and individuals can survive longer (also often getting larger) and produce more offspring. The theoretical basis for these results is grounded on the simple fact that the size of a population is determined by the balance between mortality, natality, immigration and emigration and that, therefore, reducing mortality and ensuring suitable habitats should increase the size and number of individuals living within a PA. The frequently documented empirical corroboration of this rationale (Halpern \& Warner 2002, Lubchenco et al. 2003, 2007, Micheli et al. 2004, Lester et al. 2009) has sparked interest in, and strong advocacy for, the creation of more PAs to reduce ongoing biodiversity losses (Pimm et al. 2001, Lubchenco et al. 2003, 2007, Chape et al. 2005, Game et al. 2009, Lester et al. 2009, Gaines et al. 2010, Gray 2010). Unfortunately, this interest has grown without full consideration of the shortcomings of PAs. Although numerous reviews and meta-analyses have built the case for increased use of PAs (Pimm et al. 2001, Halpern \& Warner 2002, Lubchenco et al. 2003, 2007, Micheli et al. 2004, Lester et al. 2009, Gaines et al. 2010), few have dealt with failures of PAs or with the general effectiveness of PAs at halting global biodiversity loss. Evaluation of the performance of PAs is critical since failure of PAs to protect biodiversity could erode public and political support for conservation. Additionally, PA performance evaluations will help determine whether alternative approaches are necessary while providing the justification to reallocate available conservation resources and human capital to them.

Here we review the literature and use available data to show that globally the use of PAs is not going to be sufficient, by itself, to offset the ongoing loss of biodiversity, and we identify the various practical and technical difficulties that may explain this. The limitations outlined here are similar for terrestrial and marine protected areas (MPAs); however, while we provide a terrestrial parallel in most cases we focus primarily on MPAs. The paper finishes with a scenario analysis of human population density and human consumption, which suggests that without an effort to directly address our overall appropriation of resources, we will be unable to stem biodiversity loss. We caution that we do not advocate abandoning the creation and use of PAs, particularly where they are preventing imminent extinctions or the loss of critical habitats, and where there is the capacity to manage them appropriately. Rather, we suggest that a concerted global effort to stabilize human population growth, reduce consumption and increase the Earth's biocapacity (e.g. by making current production endeavors more efficient through, for instance, transference of technology; Kitzes et al. 2008) offers the clearest path under which humanity could achieve sustainability on Earth before 2050renewed efforts toward these aims should provide definitive solutions to reverse ongoing biodiversity loss triggered by the expansion and increasing intensity of human stressors.

\section{PROTECTION OF BIODIVERSITY}

\section{Measuring performance of protected areas}

Most of the enthusiasm for establishing new PAs derives from results of meta-analyses showing greater richness and/or abundance (or biomass) of species within than outside individual PAs (Halpern \& Warner 2002, Lubchenco et al. 2003, 2007, Micheli et al. 2004, Lester et al. 2009). Yet numerous studies of PAs show that such an effect is not universal (Newmark 1987, Rakitin \& Kramer 1996, Thouless 1998, Epstein et al. 1999, Meijaard \& Nijman 2000, Rivard et al. 2000, Brashares et al. 2001, Rogers \& Beets 2001, Woinarski et al. 2001, Caro 2002, Parks \& Harcourt 2002, Tupper \& Rudd 2002, Edgar et al. 2004, Ashworth \& Ormond 2005, McClanahan et al. 2006, Coelho \& Manfrino 2007, Guidetti \& Sala 2007, Whitfield et al. 2007, Graham et al. 2008, Mora 2008, Western et al. 2009, Mora et al. 2011). This contrast in the outcomes of PAs might be related to differences in the characteristics of PAs such as size and year of implementation (e.g. Micheli et al. 2004, but see Cote et al. 2001), the types of regulations implemented in the PAs (Lester \& Halpern 2008), the quality of enforcement (e.g. Jennings et al. 1996, Kritzer 2004) or differences in the species assessed (e.g. harvested vs. non-harvested species [Micheli et al. 2004, Guidetti \& Sala 2007] or species exposed to threats other than harvesting [Jones et al. 2004, Graham et al. 2008]). Another suggested possibility is that available information is biased by the tendency to publish significant results (Gaston et al. 2008). Stochastic phenomena or local differences that complicate proper replication (Levin 1992), in combination with the considerable uncertainty of assessing the status and trends of populations (Hall 1998), make small-scale studies particu- 
larly prone to large variability. If this is combined with publication biases for significant and expected results, then our knowledge could be significantly biased toward cases where PAs have worked (Gaston et al. 2008). It is possible that PA failures may be just as common. In fact, several recent field studies, sampling groups of PAs using the same sampling methodology, indicate that PA failure may be more the rule than the exception (McClanahan et al. 2006, Mora et al. 2006, 2011, Guidetti \& Sala 2007, Graham et al. 2008, Mora 2008, Western et al. 2009). An additional explanation for the contrasts among the observed results for PAs is the possibility of an 'extinction debt' within PAs (Hanski \& Ovaskainen 2002, Baldi \& Voros 2006). According to this idea, initial isolation of biodiversity inside a new PA, while habitat deteriorates outside the boundaries, can lead at first to results showing 'healthier' populations inside compared to outside. However, over time, populations inside PAs can become nonviable and head toward extinction if they are too small to be self-sustaining or if they cannot persist without occasional input from other nearby (non-protected) sites (Hanski \& Ovaskainen 2002, Malanson 2002, Baldi \& Voros 2006). The initial extinction debt provides false positive results early on, but eventually, after such debt is paid, the effects of PAs may become negligible or even negative if such isolation leads to inbreeding and a reduction in genetic diversity (Bell \& Okamura 2005).

To provide a global overview of the extent to which PAs are preventing the loss of biodiversity, we compared the living planet index (which is the temporal change in the population size of 1686 vertebrate species worldwide; Hails 2008) to the global temporal trend of the area covered by PAs. The results show that the area of the Earth's land and ocean covered by PAs has increased rapidly in the past few decades (dotted lines in Fig. 1a,b). Unfortunately, terrestrial and marine biodiversity have both experienced rapid declines in the same time span (continuous lines in Fig. 1a,b). There is no way to determine if the rates of biodiversity loss would have been greater in the absence of PAs; however, these trends indicate that the positive results on local biodiversity of some large, well-connected and well-managed PAs (Lubchenco et al. 2003, 2007, Game et al. 2009, Lester et al. 2009) have been overridden in a global context.

Fig. 1 makes clear that the continuing effort to establish PAs is not coping with the challenge of falling global biodiversity. It could be argued that the failure of PAs to prevent biodiversity loss stems from their limited coverage (Rodrigues et al. 2004, Wood et al. 2008) or that such results vary by region. However, when trends of biodiversity loss are analyzed for different regions and for an ecosystem like coral reefs, a rela- tively large percentage of which are covered by MPAs (Chape et al. 2005, Mora et al. 2006), the results still hold-although the area of reefs covered by MPAs continues to increase, coral reefs continue to decline in both the Caribbean and the Pacific (Fig. 1c,d). Although marine and terrestrial PAs are considered 'one of the most significant human resource use allocations on the planet' (Chape et al. 2005, p. 463) and '...the past century's most notable conservation success' (Ervin 2003, p. 819) and although we would certainly be worse off in several ways without them, it is clear that our use of PAs is not, by itself, coping with the ongoing loss of marine and terrestrial biodiversity, and several reasons may explain this.

\section{Interpretation of results}

PAs are expected to yield greater richness, abundance and/or biomass in comparison to outside areas. When such a result is found, the usual explanation is that processes threatening survival of species have been removed or reduced inside the borders of the PA (Micheli et al. 2004, Lubchenco et al. 2007). Unfortunately, appropriate monitoring using before-aftercontrol-impact (BACI) sampling designs is only occasionally applied to PAs (Willis et al. 2003), and several alternative explanations (including an unpaid extinction debt) exist for a positive result of PAs. It is possible, for instance, that PAs were created on sites that already held higher diversity and/or abundance for reasons unrelated to harvest pressure and that this differential can persist even if protection is not particularly effective (Gaston et al. 2008). Joppa \& Pfaff (2011) demonstrated that, in $80 \%$ of the countries worldwide, preexisting land characteristics could account for half or more of the apparent effects of PAs in preventing land change. In fact, for $75 \%$ of the countries there was a strong bias toward placing PAs in areas unlikely to face habitat alteration even in the absence of protection (Joppa \& Pfaff 2009, 2011). A positive ratio in favor of PAs may also emerge if, as a result of the implementation of a PA, harvesting effort is displaced beyond its borders rather than being reduced; this will reduce the outside reference point and lead to the expected differential even though conditions for life have not improved, or have improved only marginally, inside the area of protection. If alternative jobs are not offered to harvesters (i.e. fishers, hunters, loggers, etc.), the creation of a PA will tend to displace extraction effort, but not reduce it, and in general this may not improve the overall abundance of harvested species (Hilborn et al. 2006). The extent of harvesting displacement probably varies depending on the socio-economic context, being more pronounced in developing societies, where 

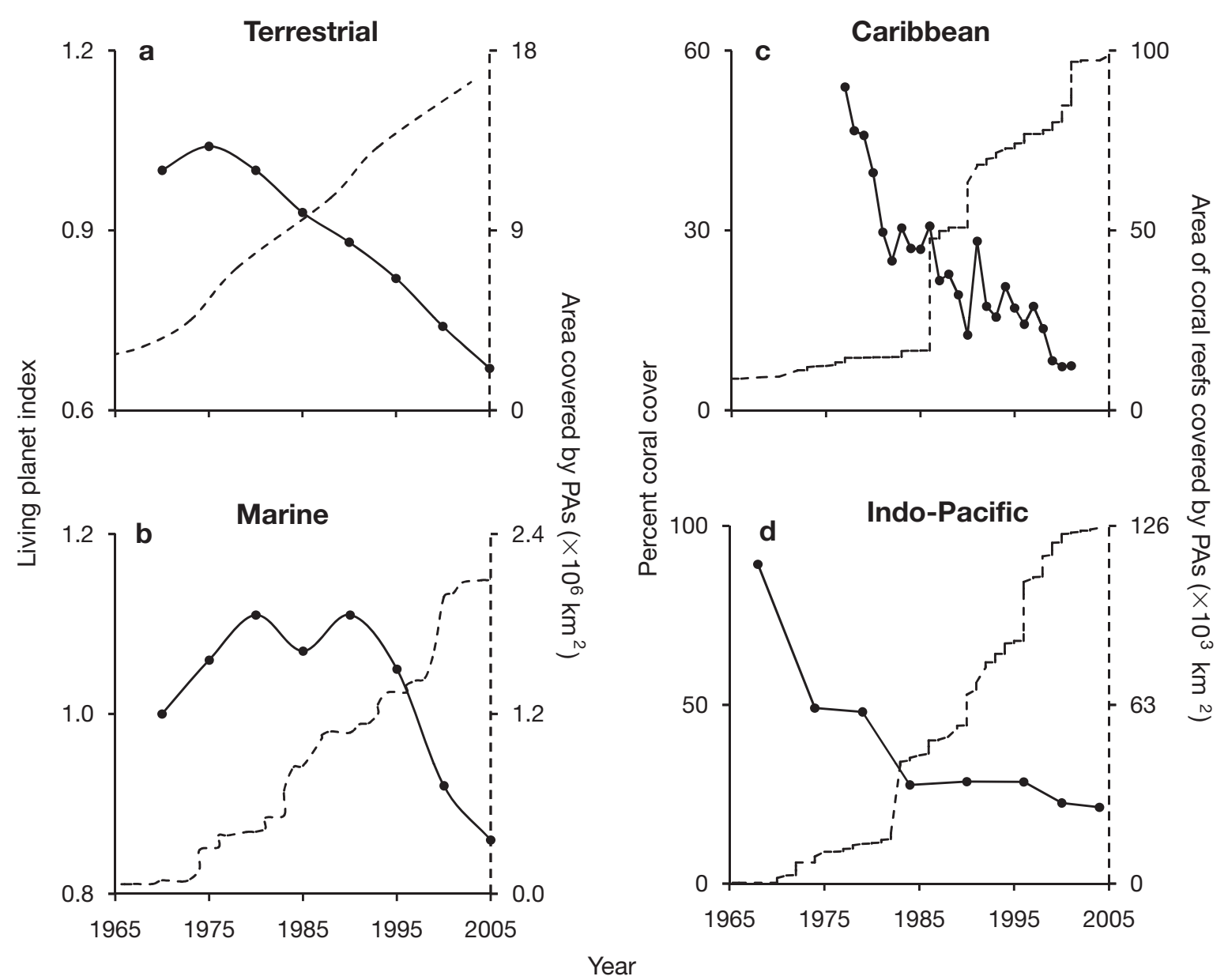

Fig. 1. Temporal trends in the areal extent of protected areas (PAs, dashed lines) and several proxies for biodiversity in marine and terrestrial ecosystems (continuous lines). $(\mathrm{a}, \mathrm{b})$ Terrestrial and marine biodiversity, respectively, in terms of the living planet index, which is the population size of $>1600$ vertebrate species worldwide (Hails 2008). (c,d) Coverage of live coral for Caribbean (Gardner et al. 2003) and Indo-Pacific reefs (Bruno \& Selig 2007), respectively. Data on the coverage of PAs on land were obtained from Chape et al. (2005); on the ocean, from Wood et al. (2008); and for Caribbean and Indo-Pacific reefs separately from Mora et al. (2006)

'poverty traps' can force harvesters into continued exploitation of even depleted resources due to the inability to move to alternative jobs (Cinner 2007, 2011). Lester et al. (2009) recently reported an analysis of a global set of 124 MPAs which found no overall tendency for displaced fishing effort; however, they acknowledge that their MPAs were likely among the better-managed ones, with many located in developed countries where alternative livelihoods were possible. Another factor requiring caution in the interpretation of the outcomes of PAs is the selection of criteria to define a positive PA effect. Edgar \& Barrett (1999) indicated that given the natural variability of ecological systems, statistically significant differences between sites can almost always be obtained; therefore, the null hypothesis for a reserve effect of no difference between sites is not adequate. Willis et al. (2003), therefore, applied a more robust criterion in which the re- sponse effect needed to be at least $100 \%$ higher than the control and found that, while a large number of case studies document 'statistically significant' effects of marine reserves, only a handful meet their more robust criterion. For the vast majority of studies the responses 'were of insufficient magnitude to confidently attribute them to a reserve effect, rather than real biological variability at the spatial and temporal level' (Willis et al. 2003, p. 100). Finally, there is the problem of scale. Variations in richness, abundance, or diversity are usually scale dependent and more pronounced on larger spatial scales; in contrast, most studies on PAs are on small scales and, as a result, the local effects of PAs may be considered trivial or absent when data are analyzed on larger scales (Guidetti \& Sala 2007, Mora et al. 2011). As noted, the interpretation of results concerning the possible effects of PAs on biodiversity requires some caution (see also Willis et al. 2003). 


\section{CHALLENGES FOR THE USE OF PROTECTED AREAS TO REVERSE GLOBAL BIODIVERSITY LOSS}

\section{Technical issues}

\section{Spatial coverage and achievement of conservation targets}

At the global scale there are $>100000$ PAs (Chape et al. 2005, Jenkins \& Joppa 2009). The most recent count indicates that 4435 are MPAs (Wood et al. 2008). The global network of PAs covers $12.9 \%$ of the Earth's land, with $5.8 \%$ having strict protection for biodiversity (Jenkins \& Joppa 2009), and $0.65 \%$ of the world's oceans, with $0.08 \%$ inside no-take MPAs (Wood et al. 2008). Political recommendations about the area of the world's ecosystems that should be inside PAs vary from $10 \%$, as recommended by the Convention on Biological Diversity, to $30 \%$, as recommended by the 2003 World Parks Congress. Ecological arguments vary concerning the amount of space that needs to be protected, reaching as high as $50 \%$ of a given area being set aside as PAs (Soulé \& Sanjayan 1998). Projections of the rate of creation of PAs in the ocean indicate that the $10 \%$ target could be reached by 2067 , the $30 \%$ target by 2092 (Wood et al. 2008) and the 50\% target by about 2105 (extrapolated from Fig. 9 in Wood et al. 2008). Assuming that the current rate of land coverage by new PAs of $0.13 \% \mathrm{yr}^{-1}$ (Jenkins \& Joppa 2009) holds constant, the $10 \%$ target could be achieved by 2043 , the $30 \%$ target by 2197 and the $50 \%$ target by 2351 . Note that these calculations may be underestimated as they assume a linear rate of expansion of PA coverage. In reality, we would expect a declining rate because competing societal needs will grow as more and more area is sequestered within PAs; thus, the conservation targets outlined above are likely to be achieved at a much later date. The creation of new PAs is clearly slow and, unfortunately, there are concerns that rushing efforts to meet conservation targets could be counter-productive if they lead to the creation of poorquality PAs or 'paper parks' (Wood et al. 2008).

Unfortunately, the limited increase in number and/or size of PAs contrasts sharply with the growing extent of human threats. For instance, demand on marine fisheries is projected to increase by $43 \%$ by 2030 to supply ongoing food demands (Delgado et al. 2003), while projected $\mathrm{CO}_{2}$ emissions by 2050 are expected to severely impact $>80 \%$ of the world's coral reefs (Donner 2009) and affect marine fish communities globally, causing local extinctions and facilitating invasions resulting in changes in species composition of up to $60 \%$ (Cheung et al. 2009). On land, the growing human population and demand for housing, food and energy are expected to substantially increase the intensity of stressors associated with the conversion of land cover to agriculture and urbanization, e.g. the release of nutrients and other pollutants, climate warming and altered precipitation (Sala et al. 2000, Millennium Ecosystem Assessment Project at www. maweb.org). In short, the extent of coverage by PAs is still limited and is growing at a slower rate than that at which biodiversity threats are developing.

\section{Population dynamics and the required size and positioning of PAs}

Many marine populations operate as a cluster of interconnected populations or metapopulations (Kritzer \& Sale 2006). The protection of these systems requires the design of networks of MPAs that are large enough to avoid the mortality of individuals crossing their borders (Kramer \& Chapman 1999, Tupper \& Rudd 2002, Palumbi 2004, Sale et al. 2005, Mora 2011) and close enough to each other so that populations can remain viably connected through propagule dispersal (Palumbi 2003, Shanks et al. 2003, Sale et al. 2005, Steneck et al. 2009, Mora 2011). The conditions of size and spacing of PAs are also critical on land, where PAs need to be sufficiently large to accommodate species' home ranges and complemented with dispersal corridors to ensure population connectivity and the viability of populations (e.g. Buechner 1987, DeFries et al. 2005).

Kramer \& Chapman (1999) provide an elegant demonstration of the trade-offs between MPA size and the individual home ranges of target species. Given the possibility of individual fish crossing MPA boundaries, fishing outside the MPA can create density gradients inside an MPA. According to their analyses, reducing fishing exposure inside an MPA to $2 \%$ of the fishing pressure outside will require MPAs to be 12.5 times larger than the home range of the individuals. Body size relates to home range such that for an average fish of $20 \mathrm{~cm}$ an effective MPA would have to be $\sim 1.8 \mathrm{~km}^{2}$ (Kramer \& Chapman 1999). In the global network of MPAs, about $30 \%$ of the MPAs are $<1$ or $2 \mathrm{~km}^{2}$ (Fig. 2a). In this large fraction of the global network of MPAs, even relatively small animals (i.e. fishes $\geq 20 \mathrm{~cm}$ ) can be lost directly to harvesting. Populations inside such small MPAs are also more vulnerable to the effects of poaching compared to those in larger ones (Kritzer 2004). The deleterious effects of small PAs, via home ranges overlapping their boundaries, also occur in terrestrial systems (Buechner 1987, Woodroffe \& Ginsberg 1998), where nearly $60 \%$ of the PAs are $<1 \mathrm{~km}^{2}$ (Fig. 2e).

The scales of propagule dispersal are perhaps one of the greatest and most crucial unknowns impacting 

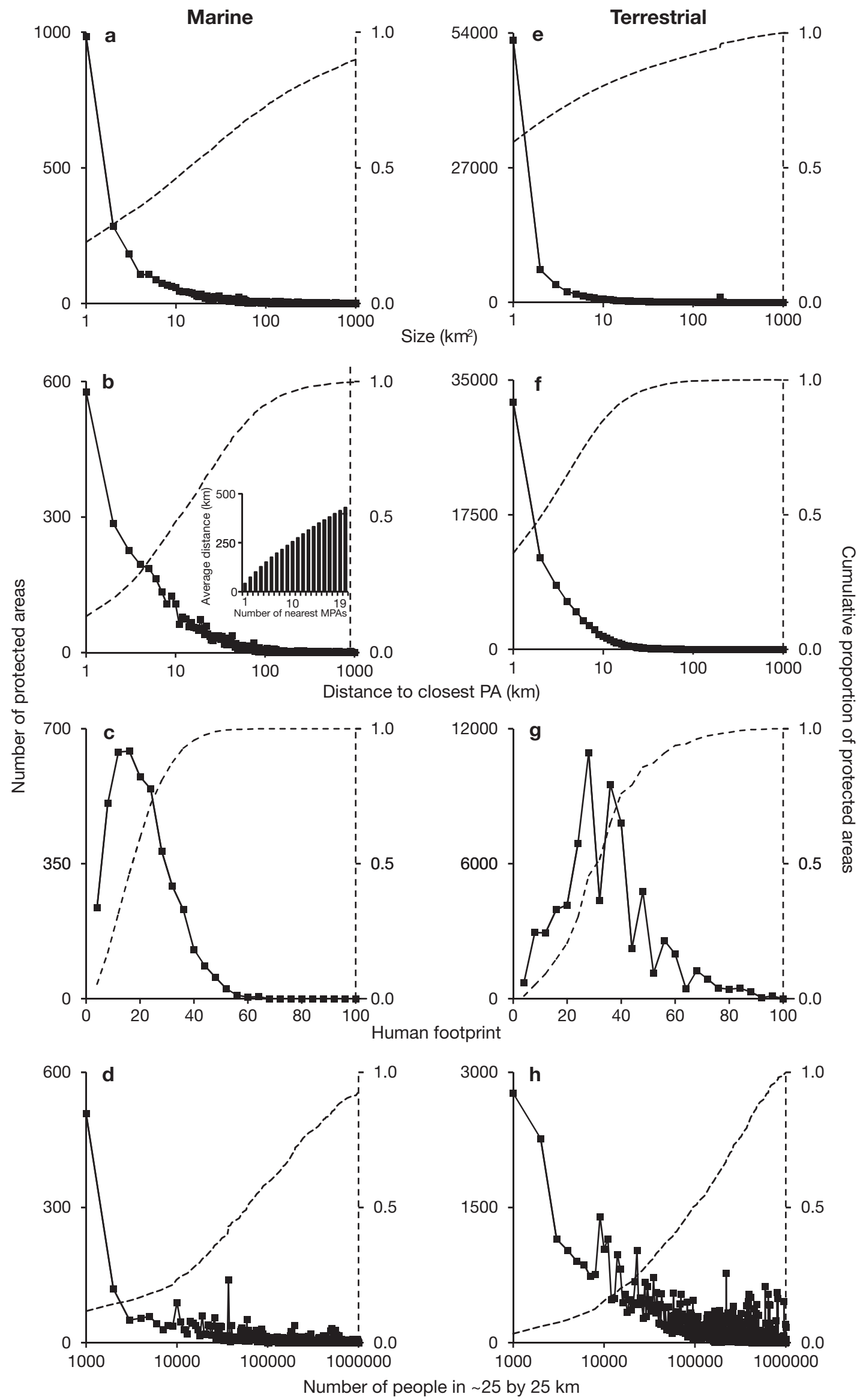
efforts to design effective MPAs (Sale et al. 2005, Steneck et al. 2009). While there is opportunity for very long-distance dispersal, the scales of most propagule dispersal are likely to fall within the order of a few tens of kilometers (Mora \& Sale 2002, Palumbi 2003, 2004, Shanks et al. 2003, Cowen et al. 2006, Jones et al. 2007). As such, recommendations about the spacing among MPAs range between 10 to $20 \mathrm{~km}$ (Shanks et al. 2003) and 20 to $150 \mathrm{~km}$ (Palumbi 2003). At the global scale, the average distance between adjacent (nearest neighbor) MPAs is $42 \mathrm{~km}$ (Fig. 2b), although this isolation increases considerably when $>1$ neighboring MPA is considered (Fig. 2b). For instance, the average distance from any MPA to the nearest 20 MPAs is $\sim 430 \mathrm{~km}$ (inset, Fig. 2b). At the global scale, establishing a network of MPAs to ensure coral reef connectivity in the range of $15 \mathrm{~km}$ would require nearly 3 times the number of existing MPAs on coral reefs (Mora et al. 2006). On land, PAs are clearly closer together, with $>50 \%$ of the PAs having their closest PA within $<3 \mathrm{~km}$ (Fig. 2f); the challenge on land, however, is that the mechanisms of dispersal of most terrestrial animals often require direct connectors ('dispersal corridors') between PAs to ensure the viability of populations (e.g. DeFries et al. 2005). In addition to making populations inside PAs non-viable, the consequences of isolation can also include inbreeding and reduction in genetic diversity, further compromising the species' resilience to disturbances (Bell \& Okamura 2005).

\section{Variety of human threats}

At the global scale, harvesting is one of 4 primary threats to biodiversity. The other 3 are habitat loss due to human appropriation of sites to fill other societal requirements, direct extirpation by an increasing number of invasive species introduced by global trade, and the alteration of habitats into ones no longer suitable for particular species due to climate change and pollution (Fig. 3). Effects of invasive species, and changes to habitat due to climate change or pollution, are not ones that are usually regulated as part of the management of a PA (Jameson et al. 2002, McClanahan et al. 2002) and unfortunately they can have as devastating effects on populations as do harvesting and habitat loss (Mora \& Ospina 2001, 2002, McClanahan et al. 2002, Mora et al. 2007). Using the developed values for the combined intensity of different human stressors on the oceans (Halpern et al. 2008) and on land (Sanderson et al. 2002 ), we found that $>83 \%$ of the current global network of MPAs and $95 \%$ of that on land are located in areas of high human impact (Fig. 2c,g). Unfortunately, most of the Earth's surface is heavily affected by human activity, leaving only limited areas $(3.7 \%$ of the ocean's surface [Halpern et al. 2008] and between 2 and $17 \%$ of the land's surface [Sanderson et al. 2002]) where PAs could effectively protect biodiversity independent of the broad array of human impacts. The expected increase in human population size, likely to be accompanied by an expansion and intensity of anthropogenic disturbances (e.g. Millennium Ecosystem Assessment Project; www.maweb.org), will exacerbate the stressors inside PAs and reduce the opportunities to site new PAs in suitable habitats.

Human stressors not regulated in PAs can preclude the benefits of even well-managed PAs. In the case of coral reefs, for instance, MPAs can have no direct effects on preventing the loss of corals due to warming, acidification, or pollution (Jones et al. 2004, Coelho \& Manfrino 2007, Graham et al. 2008, Mora 2008). Given that corals play a key role in the supply of food and a structurally complex habitat offering fish protection against predators, many species of fish inside wellmanaged MPAs have experienced comparable population declines due to the effects of coral loss, as have fish outside MPA borders (Jones et al. 2004, Graham et al. 2008). Graham et al. (2011) showed that up to $41 \%$ (i.e. 56 of 134 species studied) of the tropical reef fishes across the Indian Ocean could be vulnerable to ocean warming via the loss of coral reefs as their source of food and shelter and that species vulnerable to climate change were seldom those at risk from overfishing and other human impacts. Unfortunately, expected $\mathrm{CO}_{2}$ emissions are yielding worrisome scenarios for the viability of coral reef species and indirectly for reef fishes due to the loss of their main sources of habitat and food. For instance, increasing $\mathrm{CO}_{2}$ emissions are expected to significantly impair the calcification (due to acidification) and survival (due to warming) of coral reefs and to reduce the thresholds of coral-alga phase shifts even under optimum levels of grazing and nutrients (Anthony et al. 2011). Anthony et al. (2011) suggested that even well-managed MPAs, where grazing

Fig. 2. Absolute and cumulative frequency distributions of the world's protected areas (PAs; data from the 2009 World's Database on Protected Areas, at www.wdpa.org/) according to their $(\mathrm{a}, \mathrm{e})$ size, $(\mathrm{b}, \mathrm{f})$ isolation, $(\mathrm{c}, \mathrm{g})$ exposure to human threats and $(\mathrm{d}, \mathrm{h})$ human density. Isolation was measured as the distance to the nearest PA (inset in [b] is the mean distance to the closest 20 PAs). Exposure to human threats was measured using human footprint scores (see Sanderson et al 2002, Halpern et al. 2008); a modal score was used when multiple footprint scores existed within a PA. Human population density was estimated within the PA and an arbitrary $50 \mathrm{~km}$ buffer zone with a grid resolution of $\sim 25 \times 25 \mathrm{~km}$; data for the year 2000 from the Gridded Population of the World, Version 3, http://sedac.ciesin.columbia.edu/gpw/). All $x$-axes are log-scaled except in (c,g) 

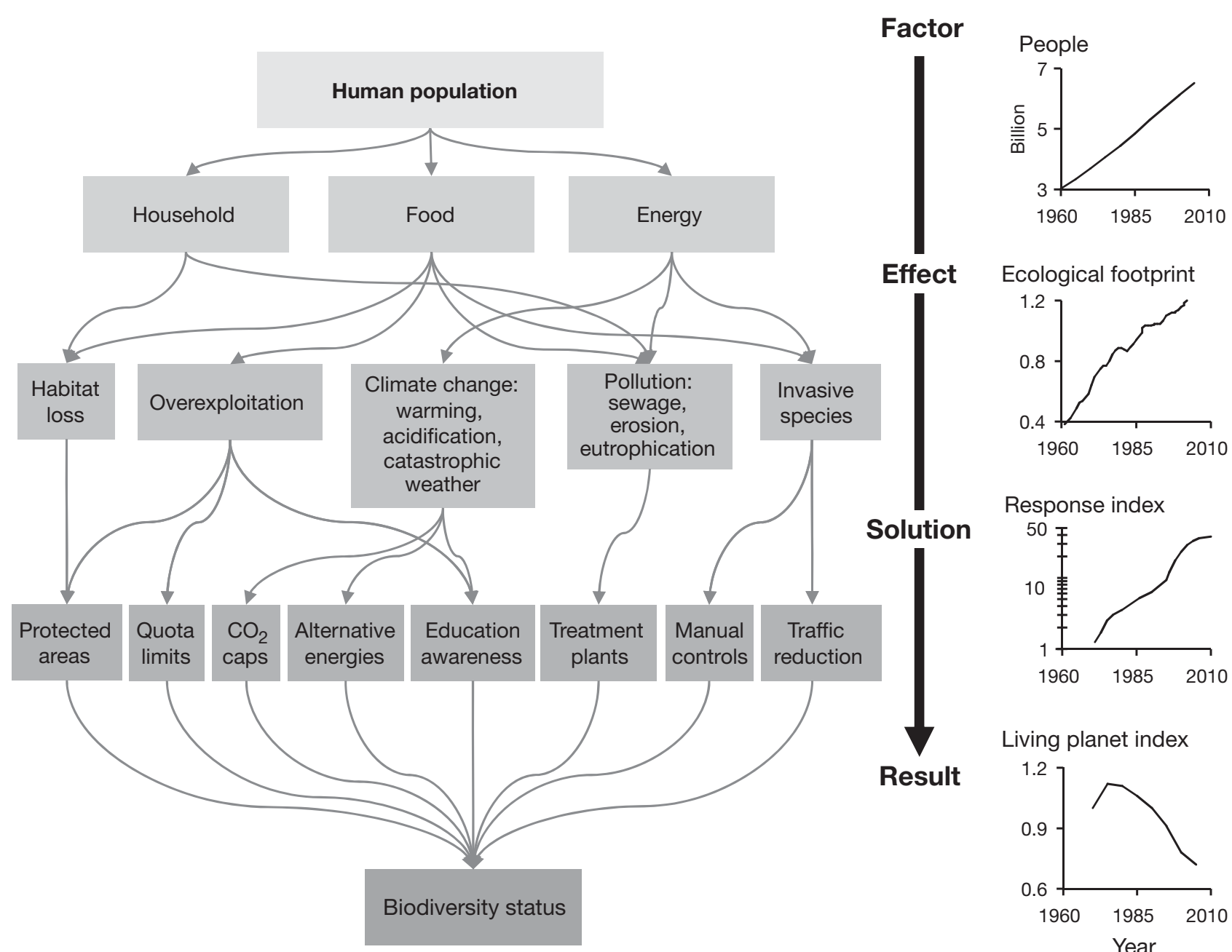

Fig. 3. Mechanism of human effect on biodiversity. Left: Cascade showing the connections between human population, human needs, effects on biodiversity and conservation measures. Right: Actual temporal trend of the world's human population (from the United Nations World Human Population Prospects, http://esa.un.org/unpp/), ecological footprint of the world's human population (from Fig. 1b in Kitzes et al. 2008), response index (i.e. combined extent of conservation strategies such as protected area extent and biodiversity coverage, policy responses to invasive alien species, sustainable forest management and biodiversity-related aid; from Fig. 2c in Butchart et al. 2010) and trend in the global living planet index as a proxy for biodiversity status (data from Hails 2008)

and nutrients are regulated, could be 'futile in the longer term' for coral reefs under high $\mathrm{CO}_{2}$ emissions and that only a concerted effort to curb $\mathrm{CO}_{2}$ emissions (i.e. low $\mathrm{CO}_{2}$ scenarios) may increase the chances of maintaining coral-dominated reefs. Another constraint to the effectiveness of well-managed MPAs is the fact that the life history of many marine species involves travelling through many different environments, where they can be vulnerable to factors other than harvesting and habitat loss. For example, the viability of most marine populations relies on the supply of propagules (Caley et al. 1996); thus, recruitment failures associated with intense early mortality due to acute environmental stressors (Walther et al. 2002, Rijnsdorp et al. 2009) would be expected to render moot any positive responses of populations once inside MPAs (Munday et al. 2009). Likewise, many coastal habitats, such as estuaries and mangroves, provide critical nursery habitat for organisms that spend most of their lives further offshore (Mumby et al. 2004). These coastal habitats are disappearing due to factors such as sea level rise, eutrophication, coastal development and sedimentation, none of which are modified by the usual management programs for PAs (Valiela et al. 2001).

In the ocean, the ecological responses of biodiversity to different human threats are intricate and pose a number of challenges to the proper design and success of MPAs. For animals with pelagic larval stages, increases in temperature might accelerate development, reducing larval period and the scales at which propagules will disperse (Almany et al. 2009, Munday et al. 2009). At the same time, habitat loss resulting 
from ocean warming, acidification and catastrophic weather might cause suitable patches to become more isolated (Hoegh-Guldberg et al. 2007). Thus, climate change, by increasing habitat isolation and reducing dispersal capabilities, can increase the extinction debts of MPAs as more and more resident populations lose viability because they lose connectivity. Similar scenarios have been described on land where climate change is displacing suitable habitats, which, depending upon migration capabilities, is causing differential impacts on species and could lead to numerous extirpations and possibly extinctions (Parmesan \& Yohe 2003, Root et al. 2003). Existing statistics suggest, for instance, that for Europe alone, between 58 and $63 \%$ of species of plants and terrestrial vertebrates could lose suitable climate inside PAs by 2080, given conservative scenarios of climate change (Araujo et al. 2011). The worldwide deterioration and increased patchiness of habitats due to human impacts is a major challenge for the biological success of even rigorously managed PAs on land and sea (Klausmeier 2001, Jameson et al. 2002, McClanahan et al. 2002).

\section{Practical issues}

\section{Budget restrictions}

The global funds expended in establishing and managing PAs are estimated at US\$6 billion $\mathrm{yr}^{-1}$ (James et al. 1999a), despite a major shortfall relative to the actual requirements for effective management. In developing countries, the deficit for effective management of PAs ranges from 66 to $74 \%$ (Bruner et al. 2004), while for MPAs worldwide the current deficit is estimated at $\sim 44.8 \%$ (Balmford et al. 2004). Troublingly, increasing the coverage of PAs to cover $20 \%$ of the world's seas would cost on the order of an additional US\$12.5 billion $\mathrm{yr}^{-1}$ (Balmford et al. 2004), and an additional US\$10.6 billion would be required to cover $15 \%$ of the land (James et al. 2001). For land alone, adding the costs of monitoring and compensation for those displaced by PAs would make the annual cost of a comprehensive network of terrestrial PAs on the order of US\$300 billion $\mathrm{yr}^{-1}$ (James et al. 1999b). A similar calculation is not available for the ocean, but the price tag could be equal or higher given the larger area of the world's oceans. Comparison of the expected costs of a well-managed network of PAs with the actual expenditure of US\$6 billion annually highlights the clear economic deficit in the current management of PAs, while pinpointing a major vulnerability limiting the chances for their expansion.

Procurement of funds to support the establishment and management of PAs is clearly a significant prob- lem, especially if the extent of PAs is to be increased. Balmford \& Whitten (2003) analyzed different funding alternatives and concluded that the principal route for covering the costs of conservation will have to be via governments combined with foreign aid from developed nations. Yet governmental investment on PAs has been limited (Balmford et al. 2004, Bruner et al. 2004). Reasons for this include the general lack of economic resources in developing nations, the need to prioritize on seemingly more critical human development issues and the limited political support for projects whose results are not evident within an electoral time frame (Soulé 1991, Wood et al. 2008). The current limited scale of transfer of resources from north to south (Balmford \& Whitten 2003) is unlikely to grow in the near future given the current global financial situation and the fact that developed countries face their own deficits in conservation spending (e.g. spending for the effective use of PAs should be increased from US\$5.3 to US\$12.6 billion annually in developed nations; James et al. 2001). In addition, there is a need for essentially perpetual funding for the management of PAs, and this is the type of expense that is not normally covered by foreign aid (McClanahan 1999). Several studies argue that the full cost of a global network of PAs could be met by redirecting a portion of the government spending on subsidies to fishing and other industries that damage biodiversity, estimated to lie between US\$0.95 and US\$1.45 trillion annually, toward the protection of biodiversity (James et al. 1999b, Balmford et al. 2004). One problem with this argument is that most subsidies are provided in developed nations, while those most in need of conservation funding are in developing countries (James et al. 2001). A second problem is that those subsidies are intended to stimulate local economies or prevent job losses and other socio-economic problems. Removing economic subsidies will require expenditure of considerable political capital, perhaps the reason why subsidies have not been diverted despite their known harm to biodiversity (Myers 1998). In short, the economic cost of an effective global network of PAs is high, whereas the funding sources appear to be limited.

\section{Conflict between the expansion of PAs and human development}

Human development goals are a major impediment to the expansion of PAs. For instance, the expected need for additional land for agriculture to meet human food requirements in 2050 would conflict with the goal of covering $50 \%$ of all land with PAs (>26\% land-use overlap; Musters et al. 2000). Similar statistics are not available for the sea; however, the conflict between conservation and access to goods and services is likely 
to be just as serious in coastal waters. For instance, Newton et al. (2007) calculated that there could be a coral reef deficit of up to $196041 \mathrm{~km}^{2}$ or about 9.6 times the size of the Great Barrier Reef to supply the food demands of human populations in tropical island countries in 2050. A second impediment related to human development goals is the potential for conflict between conservation and poverty reduction efforts due to the variable, but often negative, link between biodiversity and livelihoods in developing nations (Sanderson \& Redford 2003, Adams et al. 2004). In the past, economic development has improved human welfare, but at a huge environmental cost (Sanderson \& Redford 2003). The human development goal of bringing out of poverty the $>1.2$ billion people that live with $<\$ 1$ a day could potentially 'end ... biodiversity at the hands of the best-intended policies' should this conflict between conservation and poverty reduction efforts remain unresolved (Sanderson \& Redford 2003, p. 389). Unfortunately, strategies designed to simultaneously deliver both biodiversity protection and poverty alleviation remain elusive (Sanderson \& Redford 2003), 'overambitious and underachieving' (Adams et al. 2004).

\section{Social and political realities}

Human communities surrounding PAs can affect ecological effectiveness of such areas through poaching (Kritzer 2004) (or other non-compliance) or by triggering 'edge effects', in which mortality and habitat loss on the edges of the PA cause density gradients or increases in extinction risk inside the PA (Woodroffe \& Ginsberg 1998, Kramer \& Chapman 1999, Kritzer 2004). Lack of support by local communities can also limit the success of PAs because the inevitable noncompliance will increase enforcement costs (James et al. 1999b). Unfortunately, the current size and distribution of the world's human population make the effects of human communities on PAs a significant challenge. By overlapping the global network of marine and terrestrial PAs with a global map of human population density, we found that worldwide there are only 136 MPAs and 63 terrestrial PAs in which the boundaries and surroundings in a $50 \mathrm{~km}$ buffer were uninhabited. For the rest of the PAs, human population density was variable (Fig. 2d,h), although in general it averaged 490 people $\mathrm{km}^{-2}$ on land and 494 people $\mathrm{km}^{-2}$ in the ocean (since most MPAs are located along coastlines and many include a land component in their boundaries; this exposes MPAs to the direct effects of human communities as much as PAs located on land). The deterring effects of human communities around the boundaries of PAs may also be exacerbated; in the USA, for instance, between 1940 and 2000, nearly
1 million housing units were built within national forest parks and another 1 million are expected by 2030 within $1 \mathrm{~km}$ of PA boundaries under the current housing growth rates (Radeloff et al. 2009). The decadal housing growth rate in the 1990s within $<1 \mathrm{~km}$ from PA boundaries in the USA was $20 \%$, outpacing the national average of $13 \%$ (Radeloff et al. 2009). It has been suggested that this higher human population growth on the edges of PAs is a worldwide phenomenon, although this is a topic of current debate (Joppa et al. 2009 and references therein).

The establishment of PAs is known to generate several types of conflict among local residents, e.g. among members of a community, among communities, between communities and the state, and among stakeholder groups (Christie 2004). The nature of these conflicts is varied and may be derived from accurate or erroneous perceptions of an inequitable distribution of the benefits of protection among individuals or groups (Katon et al. 1999, Christie 2004). Conflicts may include power struggles, heavy-handed enforcement methods, competing management goals (e.g. fisheries enhancement vs. tourism development; Agardy et al. 2003, Christie et al. 2003, Christie 2004), and land- and resource-use displacement (West et al. 2006). Indeed, if conservation legislation is applied strictly, the creation of PAs on land could evict between 1 and 16 million people in Africa (Geisler \& De Sousa 2001) and nearly 4 million in India (Kothari 2004). By overlapping the global network of PAs with a global map of human population counts (data for the year 2000 from http:// sedac.ciesin.columbia.edu/gpw/), we found that by the year 2000 up to $421.9( \pm 246.4)$ million people worldwide may have been residing within the borders of PAs. (Note that the human population data are available at a resolution of $2.5^{\prime}$ or about $21 \mathrm{~km}^{2}$ in the tropics. At this resolution many cells overlap the boundaries of the PAs partially so we assumed that people are uniformly distributed within cells and estimated the number of people inside each PA by using the fraction of cell area within the PA as an estimate of the proportion of that cell's population within the PA. A measure of error was calculated by counting the number of people occurring in cases where PAs overlapped the cells on human data by $95 \%$ or less.) Clearly, strict enforcement of conservation legislation would displace and impair the livelihoods of many people; this would be aggravated if PAs were to be expanded.

Unfortunately, the resolution of social problems arising from the establishment of PAs is not easy (Adams et al. 2004). While coercive mechanisms of enforcement are often used, they always fail (Peluso 1993), at times generating violence, contravening legal and human rights (West et al. 2006), increasing the operational costs of PAs (James et al. 1999b, Balmford et al. 2004), 
and exacerbating poverty (Adams et al. 2004). The only successful approach requires that local communities understand and embrace the proposed PA program-this requires education to build social and political support (Christie et al. 2003) and 'local participation' in the design and management of PAs (Gray 2010). Gray (2010, p. 355) noted, however, that 'local and regional bodies, NGOs from developing countries and indigenous groups [have been] ... conspicuously absent' in global events and initiatives for the expansion of PAs; she presumed that this is due to the size and complexity of this endeavour, but is perhaps also due to the need to move toward the management of ecosystems over transboundary scales. The alternative of establishing PAs in zones where human use is low and conflicts are minimized is untenable, given that the extent of such areas is limited and declining rapidly worldwide. Balmford et al. (2001), for instance, showed that options for building a more comprehensive network of PAs in Africa are limited because of strong positive relationships between biodiversity and human population and because $<12 \%$ of the continent is uninhabited.

One final social constraint on the success of PAs is widespread political corruption. Soulé (1991) argues that setting aside and then effectively managing areas for protection will be improbable in states with poor and landless people, corruptible authorities, or powerful oligarchies. Unfortunately, the recent World Bank Governance Indicators show that $>90 \%$ of the countries in the world deal with serious problems of governability (in their scale from 0 to 5, 0 being the worst and 5 the best, the average governability in the world was 2.5 , with only $8 \%$ of the countries receiving grades $>4$; Kaufmann et al. 2008). Lack of governability is one of the major challenges to the success of conservation strategies worldwide.

The different shortcomings we have outlined suggest that those advocating the improvement and expansion of the global network of PAs clearly overestimate the reach of PAs and underestimate the magnitude of the challenge of reversing the ongoing biodiversity loss globally.

\section{THE WAY FORWARD}

The causes of biodiversity loss are varied and some are unlikely to be regulated as part of the management of a PA (see Fig. 3). Developing actions to address those other threats requires increased research and attention, but that is not addressed here (see Mora et al. 2009, Butchart et al. 2010). It is clear from the ongoing loss of biodiversity (Fig. 1) that current conservation efforts, whether through PAs alone or in combina- tion with other approaches, are not coping with the challenge. The data also indicate that the likelihood of success is small unless the conservation community radically rethinks the strategies needed. One could safely argue that biodiversity threats are ultimately determined by the size of the world's human population and its consumption of natural resources (Fig. 3). The explosive growth in the world's human population in the last century has led to an increasing demand on the Earth's ecological resources and a rapid decline in biodiversity (Fig. 3). According to recent estimates, about 1.2 Earths would be required to support the different demands of the 5.9 billion people living on the planet in 1999 (our Fig. 4, Kitzes et al. 2008). This 'excess' use of the Earth's resources or 'overshoot' is possible because resources can be harvested faster than they can be replaced and because waste can accumulate (e.g. atmospheric $\mathrm{CO}_{2}$ ). The cumulative overshoot from the mid-1980s to 2002 resulted in an 'ecological debt' that would require 2.5 planet Earths to pay (Kitzes et al. 2008). In a business-as-usual scenario, our demands on planet Earth could mount to the productivity of 27 planets Earth by 2050 (Fig. 4). Exceeding ecological demand beyond regenerative levels leads to the degradation of ecological capital (Kitzes et al. 2008), which is evident in the ongoing declining trend in biodiversity (Fig. 3).

Recognizing that biodiversity loss is intrinsically related to our high demand for ecological resources suggests to us that global initiatives need to address our demand for resources more directly if preservation of biodiversity is to be achieved. While we can limit human use of natural resources locally through the effective implementation of PAs, this will only address some causes of biodiversity loss, and, as shown in this review, there are numerous challenges to implement this strategy adequately across the world. As long as our demand for ecological goods and services continues to grow so will the extent of those challenges and the difficulty of using PAs to reduce biodiversity loss (Fig. 3). Therefore, alternative solutions targeting human demand for ecological goods and services, while ensuring human welfare should be prioritized and brought to the forefront of the international conservation agenda. In our view, the only scenario to achieve sustainability and to resolve the ongoing loss of biodiversity and its underlying causes will require a concerted effort to reduce human population growth and consumption and simultaneously increase the Earth's biocapacity through the transference of technology to increase agricultural and aquacultural productivity (our Fig. 4, Kitzes et al. 2008). The fact that human population growth may also lead to economic (e.g. high competition for and/or shortages of jobs; Becker et al. 1999) and societal (e.g. shortages of food 
and water, lack of universal primary education, increase in communicable disease, etc.; Campbell et al. 2007) problems suggests that targeting human population growth directly would be worthwhile and could become more effective if advocated simultaneously from social, economic and ecological perspectives.
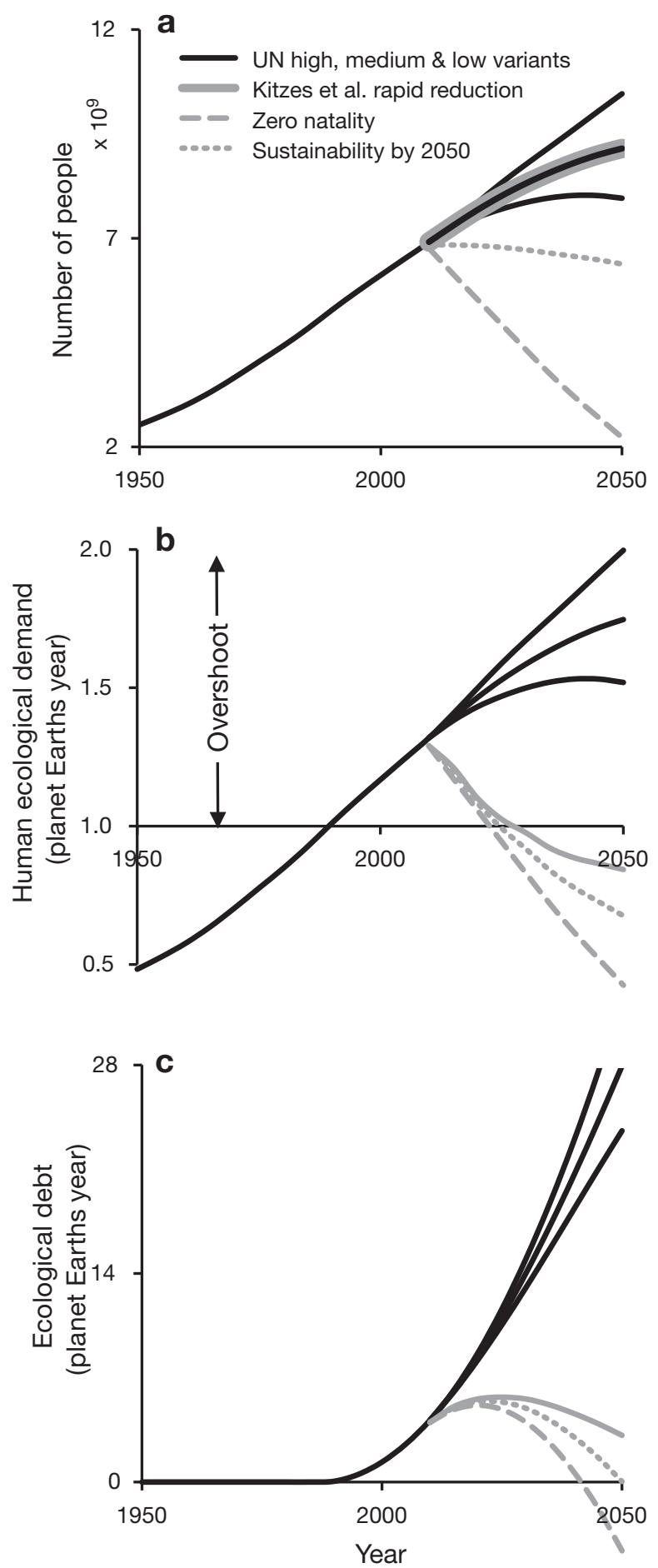

The need for a merging of ecology and economics has been recognized for the last $25 \mathrm{yr}$, ever since Vitousek et al. (1986) pointed out the high rate of cooption of primary production by our species and the lack of capacity in the biosphere to continue to provide for an increasing human population. There has been significant progress (e.g. Arrow et al. 1995, Costanza 1996, O'Neill 1996), and an explicit call for a restructuring of world views to bring them into line with a world of finite resources has been made (Beddoe et al. 2009). Apart from continuous growth being ecologically untenable, the negative economic effects of population growth need greater recognition. Independent of whether the human use of natural resources is the ultimate driver of biodiversity loss, it is clear that the range, and growing seriousness, of human threats is too great to be addressed through creation of more PAs. The inexorable and steep loss of biodiversity and the fact that it is leading to the irreversible loss of many species suggest that we cannot afford much delay before choosing the right solution to this problem.

Fig. 4. Projections for (a) human population size, (b) human ecological demand and (c) ecological debt under different scenarios of human population growth and use of natural resources. Ecological demand is calculated by multiplying the size of the world's human population by the average yearly demands of a person and dividing this amount by the Earth's biocapacity; this yields the number of planet Earths required to meet the whole human demand. Ecological debt is calculated as the cumulative ecological demand beyond the Earth's biocapacity; this is also referred as 'overshoot'. We ran a business-as-usual scenario (black solid lines) considering the United Nations projections on human population size (http://esa.un.org/unpp/), the current average annual consumption per person (in terms of area necessary to meet consumption demands) and Earth's biocapacity (i.e. 2.1 and 11 billion ha in 2002, respectively; Kitzes et al. 2008). We also show projections under the 'rapid reduction' scenario suggested by Kitzes et al. (2008) (grey solid line obtained directly from Fig. 3 in Kitzes et al. 2008). In this scenario, the Earth's biocapacity increased by $20 \%$ (e.g. through transference of technology for improving agriculture and aquaculture production) and demand by 2050 decreased by reducing $\mathrm{CO}_{2}$ emissions and fisheries catches by $50 \%$, and by stabilizing urban land expansion among other things. Using Kitzes et al.'s (2008) 'rapid reduction' scenario, we modeled the tendency of overshoot to reach zero in 2050 ('sustainability by $2050^{\prime}$ scenario) and calculated the ecological demand and number of people under that scenario accordingly. That result suggests that to get out of an overshoot by 2050, we would have to implement the conditions of the 'rapid reduction' scenario plus stabilize human population at its current size (see dotted line in [a]). This could be achieved by reducing the current birth rate of 0.01995 to the current mortality rate of 0.0082 or $\sim 1$ child per women by 2050 . As reference we also provide projections given current human consumption (i.e. 2.1 ha per person) and no further natality ('zero natality' scenario) 
Acknowledgements. We thank 4 anonymous referees for helpful comments. We thank the World Database of Protected Areas, the Gridded Population of the World Database and the United Nations World Human Population Prospects for making their data freely available. Open Access for the Theme Section on Coastal Zone Management is sponsored by the Marine Alliance for Science and Technology for Scotland (MASTS) Coastal Zone Joint Research Theme.

\section{LITERATURE CITED}

Adams WM, Aveling R, Brockington D, Dickson B and others (2004) Biodiversity conservation and the eradication of poverty. Science 306:1146-1149

Agardy T, Brigewater P, Crosby MP, Day J and others (2003) Dangerous targets? Unresolved issues and ideological clashes around marine protected areas. Aquat Conserv 13:353-367

Almany GR, Connolly SR, Heath DD, Hogan JD and 5 others (2009) Connectivity, biodiversity conservation and the design of marine reserve networks for coral reefs. Coral Reefs 28:339-351

Anthony KRN, Maynard JW, Diaz-Pulido G, Mumby PJ, Marshall P, Cao L, Hoegh-Guldberg O (2011) Ocean acidification and warming will lower coral reef resilience. Glob Change Biol 17:1798-1808

> Araujo MB, Alagador D, Cabeza M, Nogues D, Thuiller W (2011) Climate change threatens European conservation areas. Ecol Lett 14:484-492

Arrow K, Bolin B, Costanza R, Dasgupta P and others (1995) Economic growth, carrying capacity, and the environment. Science 268:520-521

Ashworth JS, Ormond RFG (2005) Effects of fishing pressure and trophic group on abundance and spillover across boundaries of a no-take zone. Biol Conserv 121:333-344

Baillie JEM, Hilton-Taylor C, Stuart SN (2004) 2004 IUCN Red List of threatened species. A global species assessment. IUCN Press, Cambridge

Baldi A, Voros J (2006) Extinction debt of Hungarian reserves: a historical perspective. Basic Appl Ecol 7:289-295

Balmford A, Whitten T (2003) Who should pay for tropical conservation, and how could the costs be met? Oryx 37:238-250

Balmford A, Moore JL, Brooks T, Burges N, Hansen LA, Williams P, Rahbek C (2001) Conservation conflicts across Africa. Science 291:2616-2619

Balmford A, Gravestock P, Hockley N, McClean CJ, Roberts CM (2004) The worldwide costs of marine protected areas. Proc Natl Acad Sci USA 101:9694-9697

Becker GS, Glaeser EL, Murphy KM (1999) Population and economic growth. Am Econ Rev 89:145-149

Beddoe R, Costanza R, Farley J, Garza E and others (2009) Overcoming systemic roadblocks to sustainability: the evolutionary redesign of worldviews, institutions, and technologies. Proc Natl Acad Sci USA 106:2483-2489

Bell JJ, Okamura B (2005) Low genetic diversity in a marine nature reserve: re-evaluating diversity criteria in reserve design. Proc R Soc Lond B Biol Sci 272:1067-1074

Brashares J, Arcese P, Sam M (2001) Human demography and reserve size predict wildlife extinction in West Africa. Proc R Soc Lond B Biol Sci 268:2473-2478

Bruner AG, Gullison RE, Balmford A (2004) Financial costs and shortfalls of managing and expanding protected-area systems in developing countries. Bioscience 54:1119-1126

Bruno JF, Selig ER (2007) Regional decline of coral cover in the Indo-Pacific: timing, extent, and subregional comparisons.
PLoS ONE 2:e711

Buechner M (1987) Conservation in insular parks: simulation models of factors affecting the movement of animals across park boundaries. Biol Conserv 41:57-76

> Butchart SHM, Walpole M, Collen B, van Strien A and others (2010) Global biodiversity: indicators of recent declines. Science 328:1164-1168

Caley MJ, Carr MH, Hixon MA, Hughes TP, Jones GP, Menge BA (1996) Recruitment and the local dynamics of open marine populations. Annu Rev Ecol Syst 27:477-500

Campbell M, Cleland J, Ezeh A, Prata N (2007) Return of the population growth factor. Science 315:1501-1502

Caro TM (2002) Factors affecting the small mammal community inside and outside Katavi National Park, Tanzania. Biotropica 34:310-318

Chape S, Harrison J, Spalding M, Lysenko I (2005) Measuring the extent and effectiveness of protected areas as an indicator for meeting global biodiversity targets. Philos Trans R Soc Lond B 360:443-455

Cheung WWL, Lam VWY, Sarmiento JL, Kearney K, Watson R, Pauly D (2009) Projecting global marine biodiversity impacts under climate change scenarios. Fish Fish 10:235-251

Christie P (2004) Marine protected areas as biological successes and social failures in Southeast Asia. Am Fish Soc Symp 42:155-164

Christie P, MaCay BJ, Miller ML, Lowe C and others (2003) Toward developing a complete understanding: a social science research agenda for marine protected areas. Fisheries 28:22-26

Cinner JE (2007) Designing marine reserves to reflect local socioeconomic conditions: lessons from long-enduring customary management. Coral Reefs 26:1035-1045

Cinner JE (2011) Social-ecological traps in reef fisheries. Global Environ Change (in press). doi:10.1016/j.gloenvcha.2011. 04.012

Coelho VR, Manfrino C (2007) Coral community decline at a remote Caribbean island: marine no-take reserves are not enough. Aquat Conserv 17:666-685

- Costanza R (1996) Ecological economics: reintegrating the study of humans and nature. Ecol Appl 6:978-990

- Costanza R, D'Arge R, de Groot R, Farber S and others (1997) The value of the world's ecosystem services and natural capital. Nature 387:253-260

Cote IM, Mosqueira I, Reynolds JD (2001) Effects of marine reserve characteristics on the protection of fish populations: a meta-analysis. J Fish Biol 59:178-189

Cowen RK, Paris CB, Srinivasan A (2006) Scaling of connectivity in marine populations. Science 311:522-527

DeFries R, Hansen A, Newton AC, Hansen MC (2005) Increasing isolation of protected areas in tropical forests over the past twenty years. Ecol Appl 15:19-26

Delgado C, Wada N, Rosegrant M, Meijer S, Ahmed M (2003) Outlook for fish to 2020: meeting global demand. International Food Policy Research Institute, Washington, DC

$>$ Donner SD (2009) Coping with the commitment: projected thermal stress on coral reefs under different future scenarios. PLoS ONE 4:e5712

- Edgar GJ, Barrett NS (1999) Effects of the declaration of marine reserves on Tasmanian reef fishes, invertebrates and plants. J Exp Mar Biol Ecol 242:107-144

Edgar GJ, Bustamante RH, Farina JM, Calvopina M, Martinez C, Toral-Granda MV (2004) Bias in evaluating the effects of marine protected areas: the importance of baseline data for the Galapagos Marine Reserve. Environ Conserv 31: 212-218

Epstein N, Bak RPM, Rinkevich B (1999) Implementation of a 
small-scale 'no-use zone' policy in a reef ecosystem: Eilat's reef lagoon six years later. Coral Reefs 18:327-332

Ervin J (2003) Protected area assessments in perspective. Bioscience 53:819-822

> Gaines SD, Lester SE, Grorud-Colvert K, Costello C, Pollnac R (2010) Evolving science of marine reserves: new developments and emerging research frontiers. Proc Natl Acad Sci USA 107:18251-18255

Game ET, Grantham HS, Hobday AJ, Pressey RL and others (2009) Pelagic protected areas: the missing dimension in ocean conservation. Trends Ecol Evol 24:360-369

Gardner TA, Cote IM, Gill JA, Grant A, Watkinson AR (2003) Long-term region-wide declines in Caribbean corals. Science 301:958-960

> Gaston KJ, Jackson SE, Cantu-Salazar L, Cruz-Pinon G (2008) The ecological performance of protected areas. Annu Rev Ecol Syst 39:93-113

Geisler C, De Sousa R (2001) From refuge to refugee: the African case. Public Adm Dev 21:159-170

Graham NAJ, McClanahan T, MacNeil MA, Wilson SK and others (2008) Climate warming, marine protected areas and the ocean-scale integrity of coral reef ecosystems. PLoS ONE 3:e3039

Graham NAJ, Chabanet P, Evans RD, Jennings S and others (2011) Extinction vulnerability of coral reef fishes. Ecol Lett 14:341-348

Gray NJ (2010) Sea change: exploring the international effort to promote marine protected areas. Conserv Soc 8:331-338

> Guidetti P, Sala E (2007) Community-wide effects of marine reserves in the Mediterranean Sea. Mar Ecol Prog Ser 335: $43-56$

Hails C (2008) Living. Planet report :2008. WWF International, Zürich

Hall SJ (1998) Closed areas for fisheries management-the case consolidates. Trends Ecol Evol 13:297-298

> Halpern BS, Warner RR (2002) Marine reserves have rapid and lasting effects. Ecol Lett 5:361-366

> Halpern BS, Walbridge S, Selkoe KA, Kappel CV and others (2008) A global map of human impact on marine ecosystems. Science 319:948-952

Hanski I, Ovaskainen O (2002) Extinction debt at extinction threshold. Conserv Biol 16:666-673

> Hilborn R, Micheli F, De Leo GA (2006) Integrating marine protected areas with catch regulation. Can J Fish Aquat Sci 63:642-649

> Hoegh-Guldberg O, Mumby PJ, Hooten AJ, Steneck RS and others (2007) Coral reefs under rapid climate change and ocean acidification. Science 318:1737-1742

James AA, Green MJ, Paine JR (1999a) Global review of protected areas budgets and staff. World Conservation Monitoring Center, Cambridge

> James AN, Gaston KJ, Balmford A (1999b) Balancing the Earth's accounts. Nature 401:323-324

James A, Gaston KJ, Balmford A (2001) Can we afford to conserve biodiversity? Bioscience 51:43-52

Jameson SC, Tupper MH, Ridley JM (2002) The three screen doors: Can marine 'protected' areas be effective? Mar Pollut Bull 44:1177-1183

Jenkins CN, Joppa L (2009) Expansion of the global terrestrial protected area system. Biol Conserv 142:2166-2174

Jennings S, Marshall SS, Polunin NVC (1996) Seychelles' marine protected areas: comparative structure and status of reef fish communities. Biol Conserv 75:201-209

> Jones GP, McCormick MI, Srinivasan M, Eagle JV (2004) Coral decline threatens fish biodiversity in marine reserves. Proc Natl Acad Sci USA 101:8251-8253
Jones GP, Srinivasan M, Almany GR (2007) Population connectivity and conservation of marine biodiversity. Oceanography 20:42-53

Joppa LN, Pfaff A (2009) High and far: biases in the location of protected areas. PLoS ONE 4:e8273

Joppa LN, Pfaff A (2011) Global protected area impacts. Proc R Soc Lond B Biol Sci. 278:1633-1638

Joppa LN, Loarie SR, Pimm SL (2009) On population growth near protected areas. PLoS ONE 4:e4279

Katon BM, Pomeroy RS, Garces LR, Salamanca AM (1999) Fisheries management of San Salvador Island, Philippines: a shared responsibility. Soc Nat Resour 12:777-795

Kaufmann D, Kraay A, Mastruzzi M (2008) Governance matters. VII. Governance indicators for 1996-2007. World Bank Policy Research, Washington, DC

Kitzes J, Wackernagel M, Loh J, Peller A, Goldfinger S, Cheng D, Tea K(2008) Shrink and share: humanity's present and future ecological footprint. Philos Trans R Soc Lond B 363:467-475

Klausmeier CA (2001) Habitat destruction and extinction in competitive and mutualistic metacommunities. Ecol Lett 4:57-63

Kothari A (2004) Displacement fears. Available at: www. frontlineonnet.com/fl2126/stories/20041231000108500.htm (accessed on 25 March 2010)

> Kramer DL, Chapman MR (1999) Implications of fish home range size and relocation for marine reserve function. Environ Biol Fishes 55:65-79

Kritzer JP (2004) Effects of noncompliance on the success of alternative designs of marine protected-area networks for conservation and fisheries management. Conserv Biol 18: 1021-1031

Kritzer JP, Sale PF (2006) Marine metapopulations. Academic Press, San Diego, CA

> Lester SE, Halpern BS (2008) Biological responses in marine notake reserves versus partially protected areas. Mar Ecol Prog Ser 367:49-56

Lester SE, Halpern BS, Grorud-Colvert K, Lubchenco J, Ruttenberg BI, Gaines SD, Airamé S, Warner RR (2009) Biological effects within no-take marine reserves: a global synthesis. Mar Ecol Prog Ser 384:33-46

Levin SA (1992) The problem of pattern and scale in ecology. Ecology 73:1943-1967

Lubchenco J, Palumbi SR, Gaines SD, Andelman S (2003) Plugging a hole in the ocean: the emerging science of marine reserves. Ecol Appl 13:3-7

Lubchenco J, Gaines S, Warner R, Palumbi S and others (2007) The science of marine reserves, 2nd edn, international version). Available at: www.piscoweb.org (accessed on 25 March 2011)

> Malanson GP (2002) Extinction-debt trajectories and spatial patterns of habitat destruction. Ann Assoc Am Geogr 92: 177-188

McClanahan T (1999) Is there a future for coral reef parks in poor tropical countries? Coral Reefs 18:321-325

McClanahan T, Polunin N, Done T (2002) Ecological states and the resilience of coral reefs. Conserv Ecol 6:18-45

> McClanahan TR, Marnane MJ, Cinner JE, Kiene WE (2006) A comparison of marine protected areas and alternative approaches to coral-reef management. Curr Biol 16:1408-1413

Meijaard E, Nijman V (2000) The local extinction of the proboscis monkey Nasalis larvatus in Pulau Kaget Nature Reserve, Indonesia. Oryx 34:66-70

Micheli F, Halpern BS, Botsford LW, Warner RR (2004) Trajectories and correlates of community change in no-take marine reserves. Ecol Appl 14:1709-1723 
Mora C (2008) A clear human footprint in the coral reefs of the Caribbean. Proc R Soc Lond B Biol Sci 275:767-773

Mora C (2011) Effectiveness of the global network of marine protected areas. In: Claudet J (ed) Marine protected areas: a multidisciplinary approach. Cambridge University Press, London, p 334-346

Mora C, Ospina F (2001) Thermal tolerance and potential impact of sea warming on reef fishes from Gorgona Island (eastern Pacific Ocean). Mar Biol 139:765-769

Mora C, Ospina F (2002) Experimental effects of La Nina cold temperatures on the survival of reef fishes from Gorgona Island (tropical eastern Pacific). Mar Biol 141:789-793

Mora C, Sale PF (2002) Are populations of coral reef fish open or closed? Trends Ecol Evol 17:422-428

> Mora C, Andrefouet S, Costello MJ, Kranenburg C, Rollo A, Veron J, Gaston KJ, Myers RA (2006) Coral reefs and the global network of marine protected areas. Science 312: $1750-1751$

> Mora C, Metzger R, Rollo A, Myers RA (2007) Experimental simulations about the effects of overexploitation and habitat fragmentation on populations facing environmental warming. Proc R Soc Lond B Biol Sci 274:1023-1028

Mora C, Myers R, Pitcher T, Zeller D and others (2009) Management effectiveness of the world's marine fisheries. PLoS Biol $7: \mathrm{e} 1000131$

Mora C, Aburto-Oropeza O, Ayala A, Ayotte PM and others (2011) Global human footprint on the linkage between biodiversity and ecosystem functioning in reef fishes. PLoS Biol 9:e1000606

Mumby PJ, Edwards A, Arias-Gonzalez E, Lindeman KC and others (2004) Mangroves enhance the biomass of coral reef fish communities in the Caribbean. Nature 427:533-536

Munday PL, Leis JM, Lough JM, Paris CB, Kingsford MJ, Berumen ML, Lambrechts J (2009) Climate change and coral reef connectivity. Coral Reefs 28:379-395

> Musters CJM, de Graaf HJ, ter Keurs WJ (2000) Ecology-Can protected areas be expanded in Africa? Science 287:17591760

Myers N (1998) Lifting the veil on perverse subsidies. Nature 392:327-328

> Newmark WD (1987) A land-bridge island perspective on mammalian extinctions in western North American parks. Nature 325:430-432

Newton K, Cote IM, Pilling GM, Jennings S, Dulvy NK (2007) Current and future sustainability of island coral reef fisheries. Curr Biol 17:655-658

O'Neill RV (1996) Perspectives on economics and ecology. Ecol Appl 6:1031-1033

Palumbi SR (2003) Population genetics, demographic connectivity, and the design of marine reserves. Ecol Appl 13:146158

Palumbi SR (2004) Marine reserves and ocean neighborhoods: the spatial scale of marine populations and their management. Annu Rev Environ Resour 29:31-68

Parks SA, Harcourt AH (2002) Reserve size, local human density, and mammalian extinctions in US protected areas. Conserv Biol 16:800-808

Parmesan C, Yohe GA (2003) A globally coherent fingerprint of climate change impacts across natural systems. Nature 421:37-42

Pauly D, Christensen V (1995) Primary production required to sustain global fisheries. Nature 374:255-257

Peluso NL (1993) Coercing conservation-the politics of state resource control. Global Environ Change 3:199-217

Pimm SL, Ayres M, Balmford A, Branch G and others (2001) Can we defy nature's end? Science 293:2207-2208
Radeloff VC, Steward SI, Hawbaker TJ, Gimmi U, Pidgeon AM, Flather CH, Hammer RB, Helmers DP (2009) Housing growth in and near United States protected areas limits their conservation value. Proc Natl Acad Sci USA 107:940-945

> Rakitin A, Kramer DL (1996) Effect of a marine reserve on the distribution of coral reef fishes in Barbados. Mar Ecol Prog Ser 131:97-113

Rijnsdorp AD, Peck MA, Engelhard GH, Mollmann C, Pinnegar JK (2009) Resolving the effect of climate change on fish populations. ICES J Mar Sci 66:1570-1583

Rivard DH, Poitevin J, Plasse D, Carleton M, Currie DJ (2000) Changing species richness and composition in Canadian national parks. Conserv Biol 14:1099-1109

> Rodrigues ASL, Andelman SJ, Bakarr MI, Boitani L and others (2004) Effectiveness of the global protected area network in representing species diversity. Nature 428:640-643

> Rogers CS, Beets J (2001) Degradation of marine ecosystems and decline of fishery resources in marine protected areas in the US Virgin Islands. Environ Conserv 28:312-322

Rojstaczer S, Sterling SM, Moore NJ (2001) Human appropriation of photosynthesis products. Science 294:2549-2552

Root TL, Price JT, Hall KR, Schneider SH, Rosenweig C, Pouns JA (2003) Fingerprints of global warming on wild animals and plants. Nature 421:57-60

Sala OE, Chapin FS, Armesto JJ, Berlow E and others (2000) Global biodiversity scenarios for the year 2100. Science 287: 1770-1774

Sale PF, Cowen RK, Danilowicz BS, Jones GP and others (2005) Critical science gaps impede use of no-take fishery reserves. Trends Ecol Evol 20:74-80

Sanderson SE, Redford KH (2003) Contested relationships between biodiversity conservation and poverty alleviation. Oryx 37:389-390

Sanderson EW, Jaiteh M, Levy MA, Redford KH, Wannebo AV, Woolmer G (2002) The human footprint and the last of the wild. Bioscience 52:891-904

Scheffer M, Carpenter SR (2003) Catastrophic regime shifts in ecosystems: linking theory to observation. Trends Ecol Evol 18:648-656

Secretariat of the Convention on Biological Diversity (2010) Global biodiversity outlook 3. Available at www.cbd.int/ GBO3 (accessed on 26 March 2011)

> Shanks AL, Grantham BA, Carr MH (2003) Propagule dispersal distance and the size and spacing of marine reserves. Ecol Appl 13:159-169

Soulé ME (1991) Tactics for a constant crisis. Science 253:744750

> Soulé ME, Sanjayan MA (1998) Ecology-Conservation targets: Do they help? Science 279:2060-2061

> Steneck RS, Paris CB, Arnold SN, Ablan-Lagman MC and others (2009) Thinking and managing outside the box: enlarging the footprint and coalescing connectivity networks for the resilience of coral reef ecosystems. Coral Reefs 28:367378

> Thouless CR (1998) Large mammals inside and outside protected areas in the Kalahari. Trans R Soc S Afr 53:245-255

> Tupper M, Rudd MA (2002) Species-specific impacts of a small marine reserve on reef fish production and fishing productivity in the Turks and Caicos Islands. Environ Conserv 29:484-492

Valiela I, Bowen JL, York JK (2001) Mangrove forests: one of the world's threatened major tropical environments. Bioscience 51:807-815

- Vitousek PM, Ehrlich PR, Ehrlich AH, Matson PA (1986) Human appropriation of the products of photosynthesis. Bioscience 36:368-373 
Walther GR, Post E, Convey P, Menzel A and others (2002) Ecological responses to recent climate change. Nature 416:389395

West P, Igoe J, Brockington D (2006) Parks and peoples: the social impact of protected areas. Annu Rev Anthropol 35: 251-277

Western D, Russell S, Cuthill I (2009) The status of wildlife in protected areas compared to non-protected areas of Kenya. PLoS ONE 4:e6140

Whitfield SM, Bell KE, Philippi T, Sasa M, Bolaños F, Chaves G, Savage JM, Donnelly MA (2007) Amphibian and reptile declines over 35 years at La Selva, Costa Rica. Proc Natl Acad Sci USA 104:8352-8356

Submitted: November 25, 2010; Accepted: May 16, 2011
Willis TJ, Millar RB, Babcock RC, Tolimieri N (2003) Burdens of evidence and the benefits of marine reserves: Putting Descartes before des horse? Environ Conserv 30:97-103

Woinarski JCZ, Milne DJ, Wanganeen G (2001) Changes in mammal populations in relatively intact landscapes of Kakadu National Park, Northern Territory, Australia. Austral Ecol 26:360-370

Wood LJ, Fish L, Laughren J, Pauly D (2008) Assessing progress towards global marine protection targets: shortfalls in information and action. Oryx 42:340-351

Woodroffe R, Ginsberg JR (1998) Edge effects and the extinction of populations inside protected areas. Science 280: $2126-2128$

Proofs received from author(s): June 26, 2011 